\title{
耕地に対する防風林の投影一宮崎市の計算例*
}

\author{
佐 藤 正 一 \\ （農林省九州農業試験場）
}

Calculations on the received solar radiation in the shade of windbreak at Miyazaki City.

\section{S. SATO}

(Kyüshū Agricultural Experiment Station)

\section{1. 緒言}

暴風雨・寒風に対する防風林の効果は顕著であるが， 反面また平素から防風林が耕地㳘を影ずる不利るある ので一度はこれを数量的に明らかにしておきたい。

本問題に対する解答の一方法として，防風林近傍の日 照時数・日射量の減少状態を計算から求めることを試み た。実例には単調な海岸線をもち台風被害が全国一の宮 犄市をとり, “宮崎県風害頻発地の分析的研究”の参考 資料たらしめんとしたものである。

\section{2. 防風林投影の基礎計算}

\section{(1) 算出の項目及び条件}

防風林近くの耕地は直射を受ける時間が減るのは当然 であるが，単に時間のみ考えては足りない。たとえば朝 1 時間の陰よりは日中 1 時間の陰が光熱受量の損失は大 きい。従つて以下は日照時間と日射量との二項目につい て考察する。

基礎計算は全日及び全期間（年間）を通じて完全に日 が照る状態，即ち実際の天気を無視した仮定条件におい て行う。

宮崎市は北緯 $31^{\circ} 56^{\prime}=\varphi$, 東経 $131^{\circ} 26^{\prime}$ である（以下 の計算は地方時によるので経度は無関係)。沿岸防風林は 第 1 図の如 $く$, 走向 $\beta$ は子午線より約 $15^{\circ}$ 東偏し, 計 算例は林の高さ $10 \mathrm{~m}$ 及び $15 \mathrm{~m}$ の二つの場合（それぞ れ一定高さの鉊直壁が長く続いた状態）を考える。

\section{(2) 計算の手順}

任意の日(日赤緯 $\delta$ ) の或る時刻 $t$ に扣ける太陽高度を $h$, 太陽の方位 (真南よりの角度)を $\alpha$ とすれば, 第 1 図に明かな如く樹高 $H$ の影の長さ $L$ は其の時刻には,

$$
L=H \cot h
$$

また影の先端線と防風林との距離 $D$ は,

$$
D=L \sin (\alpha+\beta)=H \cot h \cdot \sin (\alpha+\beta)
$$

但し林走向 $\beta$ は北より東への偏れを正にとる。(走向が子 午線に対して本例と対称ならば $\beta$ は負とする)。

これで任意の日, 時の影の状態はわかるから, 次㹸影 の移動を1日，及び年間についで求める。それは夏至か

\footnotetext{
* 昭和 28 年 5 月 17 日，九州支部総会にて発表
}

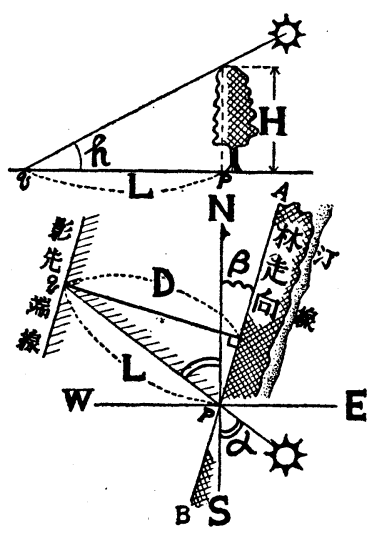

第1図防風林の影(模式図) $\beta=15^{\circ}$ MIYAZAKI City

$\left(31^{\circ} 56^{\prime} \mathrm{N}, 131^{\circ} 26^{\prime} \mathrm{E}\right)$
ら冬至まで半年分とれ ばあと半年は全く同様 であり，また本例の防 風林走向は子午線飞近 いので林西方の耕地は 午後は上く受光するか ら，1日沉いては太 陽が第 1 図のB方位に 来るまで考觉ればよ い。な打林の東側は耕 地が無く，考察範囲外 である。

筆者は毎月の 1 日と 16日をとり，其の日出 の時刻と方位, 及び毎

時の太陽高度・方位を 3)〜5) より求めた。

$\sin h=\sin \varphi \sin \delta+\cos \phi \cos \delta \cos t \cdots \cdots \cdots \cdots \cdots 3)$

$\sin \alpha=\cos \delta \sin t / \cosh \ldots \ldots \ldots \ldots \ldots \ldots \ldots \ldots \ldots \ldots)$

$\cosh \cos \alpha=-\sin \delta \sin \varphi+\cos \delta \cos t \sin \phi \cdots 5)$

実際の運算は，まず或る日については变数が $t$ の及た から計算テーブルを作つて日出及び毎時の $h$ と $\alpha$ を求 め，次に其等 $h$ と $\alpha$ に応ずる $D$ を)式により算出する のが順序である。計算は 5 桁対数表によつた。

次に或る日に括ける $t$ と $D$ の関係を図汇作れば第 2 図 左方の如く, この図から, 防風林より任意距離の地点を 林影先端が後退して直射光を受け始める時刻 $T か ゙$ 得られ 従つて当日の直射受照時間が林近傍各地点について知れ る。

次に直射光量は，第 2 図左で得た或日・或地点の直射 受计始娃刻 $T$ を第 2 図右の日射量曲線図上飞縦画線と して記し, 縦・横軸と曲線の囲む全面積（例示は半日分 の日射量) から， $T$ 縦画線より右方のかげる部分の面積 を差引いて当日の或地点の受光量を得る。林のごく近く は特に冬期は南中時以後までかげるので日射曲線を午後 の分に伸ばして前と同様に行

或る瞬時の無影平地の受ける量 $I$ は太陽高度 $h$ の正弦 


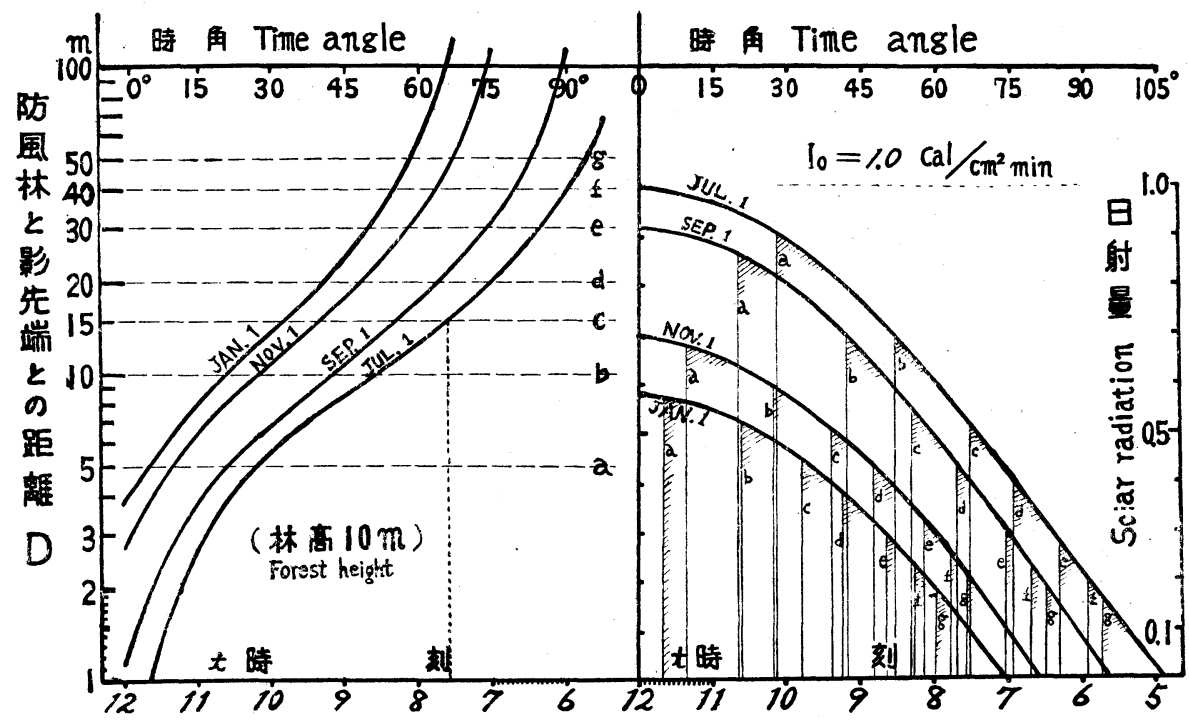

第 2 図防風林近傍の直射受始め時刻, 及びこれより直射受光量を求める図 $D$ : Distance from the forest to the top-line of the Shadow
前記の方法で計 算した結果は, 防 風林の高さ $10 \mathrm{~m}$ の場合は第 3 図, 林高 $15 \mathrm{~m}$ の場合 は第 1 表の如くで ある。

林走向が南北線 に近いので広い影 は朝の間に限られ て, 林より $50 \mathrm{~m}$ も 離れた地点は日照 時・日射量ともに 常に殆んど完全無 影地の状態に近 い。林近傍ほどお。 そくまで影が残り
に比例する。即ち

$I=I_{0} \sin h$.

となるので, 簡単のために太陽常数 $I_{0}=1.0 \mathrm{cal} / \mathrm{cm}^{2} \cdot \mathrm{min}$ とし，すでに 3)で求めた $\sin$ hの真数值そのままに熱量 単位をつけて $(t, I)$ 図としたものがこの日射量曲線であ る。

たとえば林高 $10 \mathrm{~m}$ にて 7 月 1 日に林より $15 \mathrm{~m}$ 距離 $C$ では第 2 図左により $T=7^{h} 33^{\text {r }}$ までかげるので，右の $(t, I)$ 図の 7 月 1 日に执いて此の $T$ 時刻に立てた $C$ 線を 界とし， planimeter によつて陽光を受ける部分が 222， 半日の日射全量が $263 \mathrm{Cal}$ と知られる。

\section{3. 宮崎市防風林の計算結果, 及び考察}

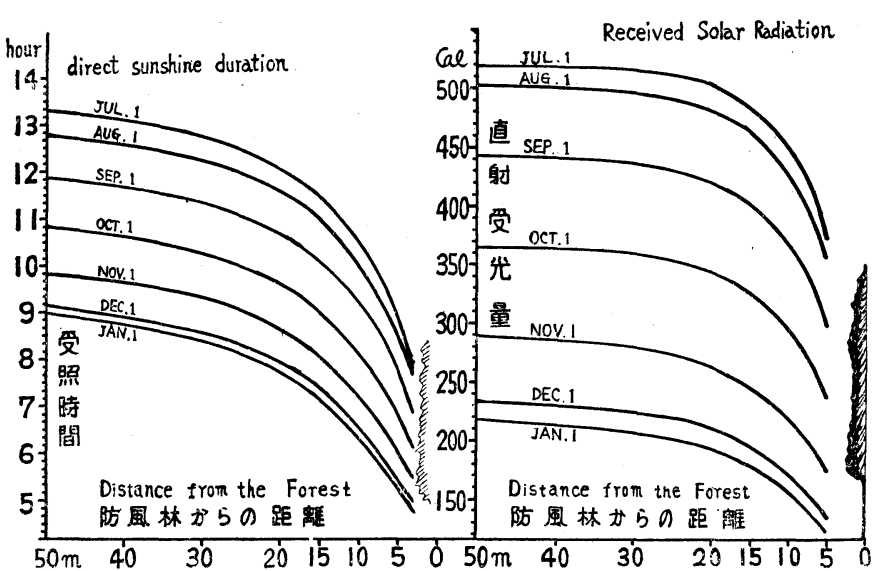

第 3 図㗬崎市，高さ $10 \mathrm{~m}$ 防風林の近傍における 1 日受照時間及び 受光量 (Forest beight： m, at MIYAZAKI)
それは冬季にその程度が大きいが, 受照時間が無影地の 半分以下となるのは林から $10 \mathrm{~m}$ 又は $15 \mathrm{~m}$ までの範囲 従つて林の高さと略々等しい距離あたりまでとみなされ る。

次に耕地水平面の受光量は, 朝からかなり長時間かげ る地点も其の後になお相当な量の日射に惠まれ，林高10 $\mathrm{m}$ の場合は $5 \mathrm{~m}$ 距離地点でも無影地に対して夏は約 7 割, 秋は 6 割である。林高 $15 \mathrm{~m}$ の場合に林から $5 \mathrm{~m}$ 距 離は無影地に対して夏は約 6 割, 秋 5 割である 林から $10,15 \mathrm{~m}$ と距たるにつれ受光量は増し, $20 \mathrm{~m}$ も離れる と常に無影地の 8 〜 割の日射量を受けることになる。

全期間 (半年分) 平均の直射受照時間減少及び直射受 光量减少状態（完全無影地に対する率） をとれば第 2 表の如くである。

以上は全期間完全な日射があるとの仮 定による計算結果である。現実の問題と しては次の諸点を考学る必要がある。

i） 林の影が明瞭にできる如き晴天日 は実さいには各月の半分内外の日数に留 まること。

ii）朝夕の太陽高度が低い時は日射量 は大気層通過距離が長いために計算值よ り弱く、また計算による無影地も実さい には地物の影や地平線近い雲による陰が 多い。

な扮計算上の陰の部分にも散光が到来 していることは云うまでもない。 
第 1 表 完全無影地及び $15 \mathrm{~m}$ 高さ防風林近傍の諸地点に 扣ける直射受照時間及び直射受光量

Sunshine duration and solar radiation at several places near the windbreak. (Forest height: $15 \mathrm{~m}$, at MIYAZAKI)

\begin{tabular}{|c|c|c|c|c|c|c|c|c|c|c|c|}
\hline \multirow{2}{*}{$\begin{array}{l}\text { 項 } \\
\text { 目 }\end{array}$} & \multirow[b]{2}{*}{ 期 } & \multirow[b]{2}{*}{ 日 } & \multirow[b]{2}{*}{ date } & \multirow{2}{*}{$\begin{array}{l}\text { 無影地 } \\
\text { at the } \\
\text { field } \\
\text { without } \\
\text { shadow }\end{array}$} & \multicolumn{7}{|c|}{$\begin{array}{l}\text { 防風林からの距離 (米) } \\
\text { distance frome the forest. }\end{array}$} \\
\hline & & & & & $\begin{array}{c}50 \mathrm{~m} \\
\mathrm{~g}\end{array}$ & $\begin{array}{l}40 \\
\mathrm{f}\end{array}$ & $\begin{array}{l}30 \\
\mathrm{e}\end{array}$ & $\begin{array}{l}20 \\
\mathrm{~d}\end{array}$ & $\begin{array}{l}15 \\
\mathrm{c}\end{array}$ & $\begin{array}{l}10 \\
b\end{array}$ & $\begin{array}{c}5 \mathrm{~m} \\
\mathrm{a}\end{array}$ \\
\hline \begin{tabular}{l|l} 
受 & \\
照 & \\
時 & \\
間
\end{tabular} & $\begin{array}{c}\text { 月日 } \\
7,1 \\
8,1 \\
9,1 \\
10,1\end{array}$ & or & $\begin{array}{l}\text { 月日 } \\
6,13 \\
5,14 \\
4,13 \\
3,14\end{array}$ & \begin{tabular}{|c|}
$\mathrm{h}$ 時, $\mathrm{m}$ 分 \\
14,04 \\
13,36 \\
12,44 \\
11,42
\end{tabular} & $\begin{array}{l}12,51 \\
12,21 \\
11,27 \\
10,23\end{array}$ & $\begin{array}{l}12,33 \\
12,04 \\
11,10 \\
10,04\end{array}$ & $\begin{array}{r}12,04 \\
11,34 \\
10,40 \\
9,34\end{array}$ & \begin{tabular}{r|r|}
11,12 \\
10,42 \\
9,49 \\
8,47
\end{tabular} & \multicolumn{2}{|c|}{$\begin{array}{r}10,309,34 \\
10,039,08 \\
9,108,18 \\
8,087,19\end{array}$} & $\begin{array}{l}8,14 \\
7,52 \\
7,11 \\
6,24\end{array}$ \\
\hline 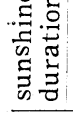 & $\begin{array}{r}11,1 \\
12,1 \\
1,1\end{array}$ & & $\begin{array}{r}2,12 \\
1,13 \\
12,13\end{array}$ & $\begin{array}{r}10,48 \\
10,06 \\
9,56\end{array}$ & $\begin{array}{l}9,25 \\
8,39 \\
8,28\end{array}$ & $\begin{array}{l}9,06 \\
8,21 \\
8,10\end{array}$ & $\begin{array}{l}8,36 \\
7,51 \\
7,42\end{array}$ & $\begin{array}{l}7,49 \\
7,04 \\
6,56\end{array}$ & \multicolumn{2}{|c|}{$\begin{array}{l}7,126,24 \\
6,315,51 \\
6,235,44\end{array}$} & $\begin{array}{l}5,36 \\
4,59 \\
4,51\end{array}$ \\
\hline $\begin{array}{l}\text { 受 } \\
\text { 光 } \\
\text { 量 }\end{array}$ & $\begin{array}{r}7,1 \\
8,1 \\
9,1 \\
10,1\end{array}$ & or & $\begin{array}{l}6,13 \\
5,14 \\
4,13 \\
3,14\end{array}$ & $\begin{array}{c}\mathrm{Cal} / \mathrm{cm}^{2} \\
526 \\
509 \\
446 \\
37.4\end{array}$ & $\begin{array}{l}519 \\
499 \\
441 \\
362\end{array}$ & \begin{tabular}{l|}
514 \\
492 \\
432 \\
356
\end{tabular} & $\begin{array}{l}505 \\
480 \\
421 \\
343\end{array}$ & $\begin{array}{l}476 \\
452 \\
390 \\
320\end{array}$ & $\begin{array}{l}451 \\
428 \\
366 \\
292\end{array}$ & $\begin{array}{l}407 \\
389 \\
330 \\
260\end{array}$ & $\begin{array}{l}335 \\
317 \\
269 \\
214\end{array}$ \\
\hline 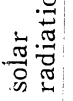 & $\begin{array}{r}11,1 \\
12,1 \\
1,1\end{array}$ & & $\begin{array}{r}2,12 \\
1,13 \\
12,13\end{array}$ & $\begin{array}{l}294 \\
240 \\
224\end{array}$ & $\begin{array}{l}284 \\
226 \\
210\end{array}$ & $\begin{array}{l}277 \\
221 \\
205\end{array}$ & $\begin{array}{l}264 \\
210 \\
194\end{array}$ & $\begin{array}{l}242 \\
189 \\
174\end{array}$ & $\begin{array}{l}221 \\
172 \\
159\end{array}$ & $\begin{array}{l}189 \\
149 \\
137\end{array}$ & $\begin{array}{l}157 \\
118 \\
107\end{array}$ \\
\hline
\end{tabular}

第 2 表 防風林近傍に打ける受照時間及び受光量の完よい。 全無影地に於けるものに対する比率の年間平均 值

annual mean ratios $s / S$ and $r / R$.

$s$ : sunshine duration at a place with shadow,

$S$ : sunshine duration at a place without shadow,

$r$ : solar radiation at a place with shadow.

$R$ : solar radiation at a place without shadow.

\begin{tabular}{|c|c|c|c|c|c|c|c|c|}
\hline \multirow{3}{*}{ 項 目 } & \multirow{3}{*}{$\begin{array}{l}\text { height } \\
\text { of the } \\
\text { forest } \\
\text { 防風林 } \\
\text { の高さ }\end{array}$} & \multicolumn{7}{|c|}{$\begin{array}{l}\text { distance from the forest. } \\
\text { 防風林からの距離 (米) }\end{array}$} \\
\hline & & $50 \mathrm{~m}$ & 40 & 30 & 20 & 15 & 10 & $5 \mathrm{~m}$ \\
\hline & & $g$ & $\mathrm{f}$ & $\mathrm{e}$ & d & c & $\mathrm{b}$ & a \\
\hline $\begin{array}{c}\text { 受照時率 } \\
s / S\end{array}$ & $\begin{array}{l}10 \mathrm{~m} \\
15 \prime \prime\end{array}$ & $\begin{array}{l}92 \% \\
88\end{array}$ & $\begin{array}{l}90 \\
86\end{array}$ & $\begin{array}{l}87 \\
82\end{array}$ & $\begin{array}{l}82 \\
75\end{array}$ & $\begin{array}{l}77 \\
70\end{array}$ & $\begin{array}{l}70 \\
63\end{array}$ & $\begin{array}{l}58 \\
54\end{array}$ \\
\hline 日射量率 & $10 \prime \prime$ & 99 & 97 & 96 & 92 & 87 & 78 & 63 \\
\hline$r / R(\%)$ & $15 \prime \prime$ & 97 & 95 & 92 & 85 & 78 & 69 & 56 \\
\hline
\end{tabular}

いまi)について，或る期間内に於 いて影の判然とする如き天気日数を $x$, 本曇又は雨天で影の生じない日数 をyとし，また或る地点の理論計算 による該期間平均受光率を $\boldsymbol{r}$, 天気 日数を考慮した平均受光率を $\boldsymbol{r}^{\prime}$ とす れば，量雨天では計算上明陰いずれ の地点も差は無いとみられるから。

$$
r^{\prime}=\frac{r \cdot x+1 \cdot y}{x+y}
$$

これから $r^{\prime}>r$ はすぐわかる。た とえば防風林より $5 \mathrm{~m}$ 地点の 7 月 の $r=0.7$, 宮崎市 7 月の $x=18$ 日, $y=13$ 日とすれば， $\boldsymbol{r}^{\prime}=0.82$ ，すな わち全日全期間日照ある仮定計算か ら無影地の 7 割受光のはずの此の地 点も, 実際には量雨天があるので無 影地の 8 割は受光し, 損失はさきの 理論計算值ほど大きくないと考えて

\section{4. 摘 要}

防風林の害の一つに耕地への投影が考えられ，この問 題の基本的取扱い法として林近傍の直射受照時間の減少 と直射受光量の減少を, 宮崎市の沿海防風林（走向は北 より $15^{\circ}$ 東偏, 樹高は $10 \mathrm{~m}$ 及び $15 \mathrm{~m}$ の両場合) につ き計算してみた。

全日全期間完全日射ありとの仮定計算によつても，防 風林から林高と略々等しい距離あたりまでは受照時間に おいてかなり減少するが，直射受光量の減損はそれ程で もなく相当量の日射に恵まれ（秋から冬にかけては減少 程度が増す), な和現実の気象を加味考虑すれば，林近傍 が無影地に比しさして受光上の不利は大きくなく，かな り不利なのも林のごく近傍に限られるとみられる。

\section{Résumé}

One of the disadvantages of the windbreak is that the windbreak casts shadow on the cultivated field. This paper deals with some investigations concerning the windbreak at Miyazaki City $\left(31^{\circ} 56^{\prime} \mathrm{N}, 131^{\circ} 26^{\prime}\right.$ E)。

The calculating methods are as follows.

1. Length (L) and direction of the forest-shadow.

Distance (D) from the forest to the top-line of the shadow.

......Fig. I, Formula I) \& 2)

2. Time (T) when the shadow retards towards the forest, and the direct sunshine begins to arrive at a certain place. .......Fig. 2 .

3. Comparing the duration of sunshine at several places with whole sunshine duration.

4. Comparing the received solar radiation at several places with whole solar radiation.

The loss in receiving solar radiation is marked only in the narrow band neighbouring the windbreak See Fig. 3, Tables I and 2. 